\title{
The design, fabrication, and performance evaluation of a locust bean boiler
}

\begin{abstract}
African locust bean is a leguminous plant that is rich in nutrients and is used as food condiment. The traditional method of processing this food condiment is mostly unhygienic; consume a lot of fire wood, human energy and time. Using traditional methods for boiling $33.7 \mathrm{Kg}$ of locust bean would take about 12 hours. This study attempts to mechanize the existing traditional methods of boiling locust bean by designing, constructing, and evaluating electrically powered locust bean boiler. The boiler consists of three composite drums, each with a cylindrical upper part and conical lower part. The boiling chamber is made of 304 austenitic stainless steel which contains the heating elements. Fibre glass is lodged between the steel materials as an insulator. As power is supplied to the boiler, the elements convert the electrical energy to heat energy attaining the temperature of $200.7^{\circ} \mathrm{C}$ in 5 minutes. The machine has the capacity of boiling $33.7 \mathrm{Kg}$ of locust bean in 1 hour at $90^{\circ} \mathrm{C}$. The cost of producing a unit is $\$ 20,207.5$.
\end{abstract}

Volume 6 Issue 6 - 2019

Keywords: design, locust bean, boiler, heating

\author{
Mohammed Gana Yisa,' Mohammed \\ Mamman Jiya ${ }^{2}$ \\ 'Department of Agricultural and Bioresources Engineering, \\ Kwara state University, Nigeria \\ 2Department of Agricultural Technology, College of Agriculture \\ Mokwa, Nigeria
}

\begin{abstract}
Correspondence: Mohammed Mamman, Department of Agricultural Technology, College of Agriculture Mokwa, Niger State, Nigeria, Email ikwan 156@gmail.com
\end{abstract}

Received: October 24, 2019 | Published: November 25, 2019

\section{Introduction}

The African locust bean tree belongs to the family of mimesacease of leguminesae group. It has a variety of names, like parkia bicolour, parkia clappertoniana, parkia fillicoidea, and Parkia biglobosa. The locust bean fruit consist of bunches of pods which form the edible part of the plant. Each pod contains a yellow pulp which envelopes the thin membranes that covers the brownish- black seed coat. It is known that locust bean contains $39-40 \%$ protein, $31-40 \%$ oil, $11.7-15.4 \%$ carbohydrate. ${ }^{2}$

The seeds are of high quality and very nutritious for human and animal feed. Processing of locust bean entails, threshing, washing, and cooking (boiling). ${ }^{3}$ The presence of saponin in P. biglobosa suggests the extract may be deleterious to user. This is because saponin has the property of precipitating and coagulating red blood cells. Some of the characteristics of saponins include formation of foams in aqueous solutions, haemolytic activity, cholesterol binding properties ${ }^{4}$ and bitterness. Tannins are dietary antinutrients that are responsible for the astringent taste of foods and drinks. ${ }^{5}$ They bind to both proteins and carbohydrates, which has several implications for commodities containing tannins. ${ }^{6}$

The production of locust bean seed is on the increase because of its importance as a source of important nutrients for local consumers and its importance as a commercial exploitation in the food industry. The method of its processing is still largely traditional, laborious and time consuming, resulting in products of low quality. Detailed information about the physical properties is very useful in the design of equipment for harvesting, storing, cleaning, sorting, grading, packaging and processing, thus enhancing process and quality control. ${ }^{7}$

The food condiment also called Dawadawa seed locally or African locust bean (Parkia biglobosa) has dissimilar physical and mechanical properties when compared to other legumes. The bean is encased in a hard tough and relatively thick coat that has partially-permeable characteristics. The bonding strength that covers the coat of the seed is relatively high making it difficult for water movement through the coat. Removing the coat (Decoating) of the bean in a dry condition would be difficult if not impossible and may lead to heavy losses. This can adversely impact on the total output of the famer or processor. While the target of the farmer or processor is to maximize profit. To design equipment and facilities to process "Iru", an important foodflavouring condiment made from locust bean seeds, some of the physical properties of the seeds most be determined. ${ }^{8}$ In the traditional boiling a lot of fire wood is involved and this has adverse effect on the environment as it encourages felling of trees leading to desert encroachment. Some food processes are carried out under reduced pressure to boil off moisture at reduced temperature. ${ }^{9}$ Jam making is an example of this type of process. Consequently, some processes operate at elevated pressure for instance, the process of pasteurization. Pressure cooking is also used to hasten normal cooking process in food preparation. Cooked food is food that has been changed in various ways by heat treatments. The heat may be applied in a number of ways; it may be dry or moist, which include; baking, roasting, grilling, and boiling, summering, stewing, poaching. When food is cooked in hot water, the water circulates and the heat is carried to the food by convection, though the food absorbs this heat by conduction. Increase in pressure raises the temperature at which water boils, so the boiling temperature is increased and the boiling time reduced.

Mohammed et al. ${ }^{10}$ conducted a research to develop a locust bean cubing machine. The machine was designed to cube $2 \mathrm{~kg}$ of fermented locust beans with the help of a piston-connecting rod arrangement, as a conveying mechanism. Their result showed that the machine required a piston speed and pressure of $33 \mathrm{~m} \mathrm{sec}-1$ and $25.1 \mathrm{kN} \mathrm{m}-2$, respectively. Also, the machine according to them was able to produce cubed locust beans of an approximate size of $0.06 \mathrm{~m}^{2}$. They concluded that the cubing of locust beans condiment can be successfully achieved with the help of this machine. Gas boiling or pressure cooking increased the level of water uptake by locust beans over that with 
firewood cooking, mainly because of sustained heat input. Presoaking in cold water produced no advantage. The boiling times necessary for satisfactory dehulling is $10 \mathrm{hrs}$ using firewood, $6 \mathrm{hrs}$ by gas boiling, and 30 and 50min respectively by pressure cooking at 121 and $115^{\circ} \mathrm{C} .{ }^{11}$ Oloko \& Agbetoye ${ }^{12}$ established that fermentation period of 10 days made the machine to perform well at feed rate of $20 \mathrm{~kg} / \mathrm{hr}$. Alabi et al., ${ }^{13}$ Beaumomt ${ }^{14}$ and Omafuvbe et al., ${ }^{15}$ investigated the fermentation of African locust bean and melon seeds to their respective condiment iru and ogiri and they reported that the fermentation process increases the crude protein and the extract content of the product.

The objective of upgrading an indigenous system should be to achieve a process control system, a sanitary and hygiene system as well as a system for achieving technical efficiency in terms of time, energy, labour and material use while focusing on improved product quality. An improved indigenous technology is the result of the combination of modern technological practices and traditional food processing practices. ${ }^{16}$

\section{Locust bean processing}

\section{Traditional method}

In the traditional processing method the pulp is subjected to soaking to remove the sweetened yellowish tissue from the seed, after which the dried beans are subjected to about 12 hours of intensive boiling to soften the hard seed coat. After softening, the seed coats are removed by finger pressure releasing the cotyledons which are reheated for up to two hours, after which they are drained, cooled and prepared for fermentation by packing them into incubation materials and weighed down to keep the cover in place. The seed are then left for two to three days to ferment in the natural heat of the tropics. ${ }^{2}$

\section{Treatment of water}

The basic assumption with regards to the quality of feed water is that elements like calcium, magnesium, migratory iron, migratory copper, colloidal silica, and other contaminants have been reduced to a minimum, consistent with boiler design and operational parameters. ${ }^{17}$ The goal is to improve the quality of water prior to its use as boiler feed water. Untreated water results in deposition of metallic oxides in the boiler and boiler systems. The deposition of these metallic oxides in the boiler act as insulators, which causes local overheating. It also offers an opening for further corrosion mechanisms as well. Contaminated water also causes foaming.

\section{Boiler embrittlememt}

Embrittlement of boiler metal is normally referred to as caustic embrittlement or intercrystaline cracking. Failure of a boiler due to caustic embrittlement is normally undetectable during operating conditions. It generally occurs suddenly, with catastrophic results.

Three major factors must be present to cause intercrystaline cracking in boiler metal, they include; Leakage of boiler water/steam, attack of boiler metal by concentrated caustic soda and high metal stress in the area of caustic concentration and leakage.

\section{Heat transfer}

Heat transfer is the transition of thermal energy from a hotter mass to a cooler mass. ${ }^{18}$ When the presence of a heated surface causes a liquid near it to boil, the intense agitation gives rise to high local coefficients of heat transfer. In some food processes, quick heating is required in the pan, for example, in the boiling of jam. In this case, a helical coil may be fitted inside the pan and steam admitted to the coil. This can give greater heat transfer rates than jacketed pans, because there can be a greater heat transfer surface and also the heat transfer coefficients are higher for coils than for the pan walls. ${ }^{19}$

\section{Materials and method}

\section{Material Selection}

Material selection is the process of choosing the right type of material in the construction of engineering structure and components. When selecting the materials used for the relevant parts relating to the functions coupled with the stress conditions and service life, considerations were made. The types of materials used in the construction of the equipment are important factor for technical efficiency and ease of cleaning. ${ }^{20}$ Mechanical properties such as strength, toughness, fatigue, hardness, wear and chemical properties such as resistance to oxidation were considered. The materials used in the process of construction and evaluation of the boiler include; 304 austenitic stainless steel, square pipe, carbon steel and fibre glass others are $33.7 \mathrm{~kg}$ of locust bean seed, 50,37.5, 25 and 12.5 liters of water. Other standard components used are contained in the Table 1 below. The Material selection for the construction of the boiler was based on; the material availability, suitability of the material for the design, cost of the material, Durability of Material, Maintenance cost and Ease of construction in order to achieve the desire objectives

Table I Standard components used

\begin{tabular}{ll}
\hline Name & Description \\
\hline Water valve & 2 inch water gate valve to regulate water flow \\
Bolt and nuts & 17 mm diameter bolt and nuts \\
Heating elements & Concentric conductors (constantan) \\
Fibre glass & $2 \mathrm{Kg}$ \\
\hline
\end{tabular}

\section{Design considerations}

The following factors were considered during the design of the locust bean boiler, they include; considering the machine as a food processing unit which requires hygienic and non-corrosive material for construction, leakages were highly minimized, the thicknesses of the three shells are $1.5 \mathrm{~mm}$, the heating element is constantan, steam and heat transfer losses will be minimal and that electrical supply would be uninterrupted in the cause of performance evaluation. Engineering properties of locust bean are indispensable properties in the design of the machine for boiling and separating locust bean seed. According Gbabo et al., ${ }^{21}$ Mohsenin stated that engineering properties include physical, frictional and rheological properties. The other properties considered were; Compactness, Human height and Simplicity and ease of construction.

\section{Design calculations \\ Design of the heating element}

Wire elements formed into a coil allow a suitable length of wire to be accommodated in a relatively short space, and also absorb the effects of thermal expansion. ${ }^{18}$ Under steady state conditions, a heating element dissipates as much heat from its surface as it receives the power from electric supply.

If $\mathrm{P}$ is power input and $\mathrm{H}$ is the heat dissipated by radiation, then under steady state conditions. 


$$
P=H \quad(1)
$$
by

From Stefan's law of radiation, heat radiated by hot body is given

$$
H=5.72 e k\left[\left(T_{1} \div 100\right)^{4}-\left(T_{2} \div 100\right)^{4}\right] \mathrm{W} / \mathrm{m}^{2}
$$

Where $t_{1}$ is the temperature of hot body in ${ }^{\circ} \mathrm{K}$ and $t_{2}$ is the temperature of the cold body (or cold surrounding) in ${ }^{\circ} \mathrm{K}$, then;

$$
\begin{aligned}
& P=V^{2} / R, \text { and } \\
& R=P L / A=4 P L / \pi d^{2} \\
& \pi P=V / 4 P L / \pi d^{2}=\pi d^{2} V^{2} / 4 P L \\
& L / d^{2}=\pi V^{2} / 4 L P P
\end{aligned}
$$

Total surface area of the element $=\pi d L$

If $\mathrm{H}$ is the heat dissipated by radiation per second per unit surface area of the wire, then heat

radiated per second $=(\pi d) L H$

equating eqn. 8 and 5 we have

$$
P=\left((\pi d) L H \text { or } \pi d^{2} V^{2} / 4 P L=(\pi d) H \text { or } L^{2}=V^{2}\right.
$$

Values of $\mathrm{L}$ and $\mathrm{d}$ can be found from the above equation.

\section{Calculating the length of heating element}

To calculate the resistance for a length of wire, there are a couple of things that should be considered, the first is the cross sectional area, second, the length, and the third is the Specific Resistivity for the conductor. ${ }^{23}$

The Specific Resistivity is the value of resistance for a wire.

$$
\text { If Emissivity }(e)=0.9
$$

Radiating efficiency $(k)=0.5$

Resistance $(R)=49 \times 10^{-8}$ Khurmi \& Gapta $J A^{24}$

Length of heating element $=L$

Diameter of heating element $=d$

Resistivity $=P$

Power dissipated $=H$

Voltage $V=230 \mathrm{~V}$

Area of heating element $=A$

$t_{1}=200^{\circ} \mathrm{C}$

$t_{2}=26.15^{\circ} \mathrm{C}$

Temperature of hot body in ${ }^{\circ} \mathrm{K}\left(T_{1}\right)=200^{\circ} \mathrm{C}+273^{\circ} \mathrm{K}=473^{\circ} \mathrm{K}$

Temperature of cold body or surrounding in ${ }^{\circ} \mathrm{K}\left(\mathrm{T}_{2}\right)=26.15^{\circ} \mathrm{C}+273=299.15^{\circ} \mathrm{K}$

from equation 6 we have

$$
\begin{gathered}
L / d^{2}=A V / 4 P P \quad(10) \\
=\left[\pi \times(230)^{2}\right] / 4 \times 49 \times 10^{-8} \times 2500 \\
L / d^{2}=166211.8 / 0.0049=33920775.51
\end{gathered}
$$

From Stefan's equation we have

$$
\begin{aligned}
H= & 5.72 e k\left[\left(T_{1} \div 100\right)^{4}-\left(T_{2} \div 100\right)^{4}\right] \mathrm{W} / \mathrm{m}^{2} \\
& =5.72 \times 0.9 \times 0.5[(4.73) 4-(2.99) 4]
\end{aligned}
$$

We know from eqn. 9 that

$$
=2.574[420.62]=1082.68 \mathrm{~W} / \mathrm{m}^{2}
$$

$$
\begin{aligned}
P=\pi d L \text { Handp }=2.5 \mathrm{~kW} \\
\therefore \pi L d 1082.68=2.5 \mathrm{~kW} \\
d L=0.735 \mathrm{~W}
\end{aligned}
$$

Squaring both sides

$$
d^{2} L^{2}=0.54
$$

From equation. 10 and 13 we have

$$
\begin{aligned}
& L^{3}=33920775.51 \times 0.54 \\
& =18317218.7 \\
& L=263.6 \mathrm{~m} \text { then, } \\
& \mathrm{d}==\frac{0.062024}{263.6}=0.002788 \mathrm{~m}=0.279 \mathrm{~cm}
\end{aligned}
$$

\section{Determining the required current}

To determine the voltage, current and resistance that pass through a wire, Ohms law formula is used. where $\mathrm{V}=\mathrm{I}^{*} \mathrm{R}$. V is the voltage drop across the piece of wire. I is the current flow through the wire. $\mathrm{R}$ is the resistance of the length of wire

$$
\begin{aligned}
& V=I R \\
& V=230 \\
& R=P \times L / A \\
& R=49 \times 10^{-8} \times 263.6 / 2.442 \times 10^{-5}=5.290 \mathrm{hms} \\
& \therefore 230=I \times 5.29 \\
& I=230 / 5.29=43.49 \text { amps }
\end{aligned}
$$

\section{Capacity of the machine}

Every machine has its design capacity. In the design of the volumetric capacity of the boiler, volumetric formulae for cylinder and cone were used since the upper part of the boiler is cylindrical in shape and the lower part conical in shape. The combination of the volumes gave the volumetric capacity of the boiler.

If total volume of the boiler unit=

Volume of a cylinder $\left(\pi r^{2} h\right) \mathrm{cm}^{3}+$ Volume of a cone $\left(1 /\left(3 \pi r^{2} h c m^{3}\right) \quad(16)\right.$

ठ $=3.142, \mathrm{r}_{1}=19.5 \mathrm{~cm}, \mathrm{~h}=30 \mathrm{~cm}$ which is;

$$
=35842.3 \mathrm{~cm}^{3}+17921.1 \mathrm{~cm}^{3}=53763.4 \mathrm{~cm}^{3}
$$

For inner stainless steel

$$
ð=3.142, \mathrm{r}_{2}=23 \mathrm{~cm}, \mathrm{~h}=30 \mathrm{~cm}
$$

Total volume of the inner stainless steel $=61292.5 \mathrm{~cm}^{2}+30646.28 \mathrm{~cm}^{3}=91938.84 \mathrm{~cm}^{3}$

Area of cooking chamber $=$ area of cylinder with two open ends + area of curved surface of cone $=2 \pi r h+\pi r l$

\section{Determination of power requirement}

For a machine to function efficiently within its design capacity it requires adequate amount of power. The boiler is designed to use electricity as its source of power. Simple power, voltage, and current relationship are used to obtain the power required. 


$$
\begin{gathered}
P=\text { energy transferred / time taken } \\
p=I V t / t=I V \quad(19) \\
I=43.49 \text { amps, } V=230
\end{gathered}
$$

Thus $I V=43.49 \times 230=10002.7 \mathrm{~J}$

$$
\begin{gathered}
W=Q V=I V t \\
(H)=I V t
\end{gathered}
$$

Heat in a resistor $=I V t$

$$
\begin{aligned}
t= & 1 \text { hrs } \times 60=600 \text { munute } \\
& I V t=43.49 \times 230 \times 60 \\
& =600162 \mathrm{~J} \\
& H=600.162 \mathrm{~kJ}
\end{aligned}
$$

\section{Mechanism of heat transfer}

Heat transfer is a fundamental phenomenon involved in agricultural production and food processing. In many applications, heat transfer occurs simultaneously with mass transfer. There are three mechanisms that are responsible for thermal energy transfer: convection, conduction, and radiation. These mechanisms can occur individually or in combination. ${ }^{19}$ Using the thermal circuit concept as in Figure 1, the amount of heat transferred through any medium is the quotient of the temperature change and the total thermal resistance of the medium. ${ }^{18}$ Considering the boiler as a composite system of cross- sectional area A (Figures 1\&2). The composite is made of an $\mathrm{L}_{1}$ long stainless steel with a thermal coefficient $\mathrm{k}_{1}$ and $\mathrm{L}_{2}$ long fiber glass, with thermal coefficient $\mathrm{k}_{2}$ the inner stainless steel $\mathrm{L}_{3}$ long with thermal coefficient $\mathrm{k}_{3}$ and a heating element $\mathrm{L}_{4}$ with thermal coefficient $\mathrm{k}_{4}$. The left surface of the boiler is at $\mathrm{T}_{i}$ and exposed to air with a convective coefficient of $h_{\mathrm{i}}$. The Right surface of the boiler is at $\mathrm{T}_{\mathrm{o}}$ and exposed to air with convective coefficient $\mathrm{h}_{\mathrm{o}}$.

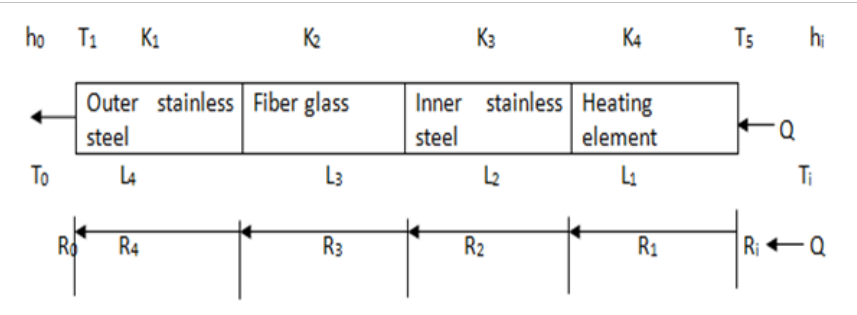

Figure I Representation of heat flow diagram as a thermal circuit.

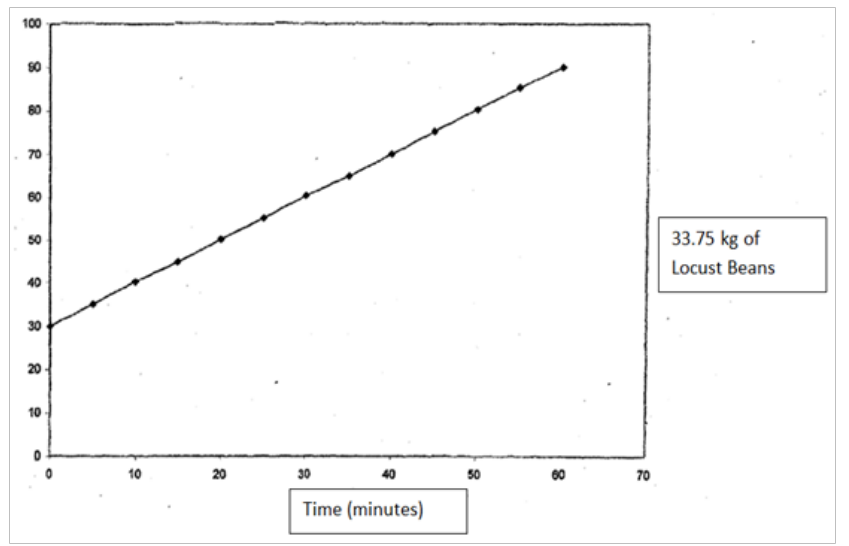

Figure 2 Relationship between temperature and time in boiling locust bean.

The heating element contained in the boiler derives its source of power from electricity. The electrical energy is being converted into heat energy by the element. During the boiling process, the water film close to the surface of the element derives heat by conduction and this heat circulates around the whole water by convection process. The locust bean conduct the heat from the water this transform gradually the locust bean seed from raw to boiled one. Part of the heat is conducted by the surface of the boiler chamber through the insulator to the outer surface of the boiler. The heat at the outer surface is lost to the environment through the process of conduction, convection and radiation.

Assuming that $\mathrm{T}_{1}, \mathrm{~T}_{2}, \mathrm{~T}_{3}, \mathrm{~T}_{4}$ and $\mathrm{T}_{5}$ are known, the governing equation can be constituted as follows; ${ }^{22}$

$$
\left(T_{1}-T_{5}\right)=q\left[\frac{L_{1}}{k_{1} A}+\frac{L_{2}}{k_{2} A}+\frac{L_{3}}{k_{3} A}+\frac{L_{4}}{k_{4} A}\right]
$$

$\left(T_{1}-T_{5}\right)=$ thermal potential responsible for heat flow

$\mathrm{k}_{1,} \mathrm{k}_{2}, \mathrm{k}_{3}, \mathrm{k}_{4}=$ Thermal conductivities.

Thermal conductivity of water $=0.75 \mathrm{Jm}^{-2} \mathrm{~S}^{-10} \mathrm{C}^{-1}$

Thermal conductivity of steel $=50.2 \mathrm{~W} / \mathrm{m}^{\circ} \mathrm{C}$

\section{Cost of production}

All the materials used were sought for in the local market. The materials were readily available and the prices to which they were bought were the minimum bargained prices. The summery of the total cost is as follows.

Total material cost $=\# 14,750$

Labour cost $=3687.5(25 \%$ of material cost $)$

Overhead cost $=\# 1770(12 \%$ of material cost $)$

Grand total cost $=\# 20,207.5$

\section{Machine constructions}

In constructing the machine, Selecting the most appropriate materials and fabricating them into hygienic food-processing equipment is a process that should start by considering the detailed definitions of both the product and the process in terms of their chemistry, stresses, and temperatures, including those which may result from, for instance, vibration or 'water-hammer' or thermal shock, all of which are common in food-processing plant. In the selection of materials for the construction of the boiler, 304 austenitic stainless steel was used to construct the boiling chamber because of its formability or weldability and Corrosion resistance. Carbon steel square pipe was used in the construction of the supporting frames because of its strength. Stainless steel's inherent hardness maintains the smoothness which enables it to resist the adhesion of soils and bio-films and renders it very easy to clean and sanitize. Indeed, stainless steel has been proved in clinical tests to be significantly more hygienic than other food-contact surfaces. Claims have, of course, been made that other (non-ferritic) materials offer strong antibacterial properties by effectively poisoning virulent pathogens, so having to depend less upon the smoothness and abrasion resistance of their surfaces, but stainless steel remains hygienic without imparting any of its constituents either to pathogens or to the food being prepared. It also has good resistance to corrosion. It was ensured during the construction of the boiler that all surfaces, including the joints, were smooth and have neither ridges nor crevices which could harbor organic materials. Projections, edges and recesses were reduced to a minimum. Components were assembled by welding and bonding, using bolts and nuts. 


\section{Operational principle}

The boiler derive its power from electricity, the electrical energy is converted by the element (constantan) into heat. Adequate amount of water and locust bean is supplied as related to the capacity of the boiler. The boiler has a pressure tight cover and a fiber glass insulator which allow for maximum pressure and temperature effect. The boiler has the capacity of boiling $33.7 \mathrm{~kg}$ in $1 \mathrm{hr}$. The boiled seed is collected from the conical lower part of the machine.

\section{Performance test procedure}

A digital thermometer was used to determine the temperature changes at 5 minutes interval of heated empty boiler which attains the temperature of $200.7^{\circ} \mathrm{C}$ in 5 minutes. $50,37.5,25,12.5$ liters of water were latter supplied to the boiler and temperature changes were measured at 0.5 minutes interval up to 32.5 minutes. The results obtained are tabulated in Table 1. The boiler was then used to boil $33.7 \mathrm{~kg}$ of locust bean, Table 2 and temperature outside the boiler was also determined and tabulated in Table 3 .

\section{Results}

Tables 2 \& 3 .

Table 2 Results of performance evaluation on boiler machine

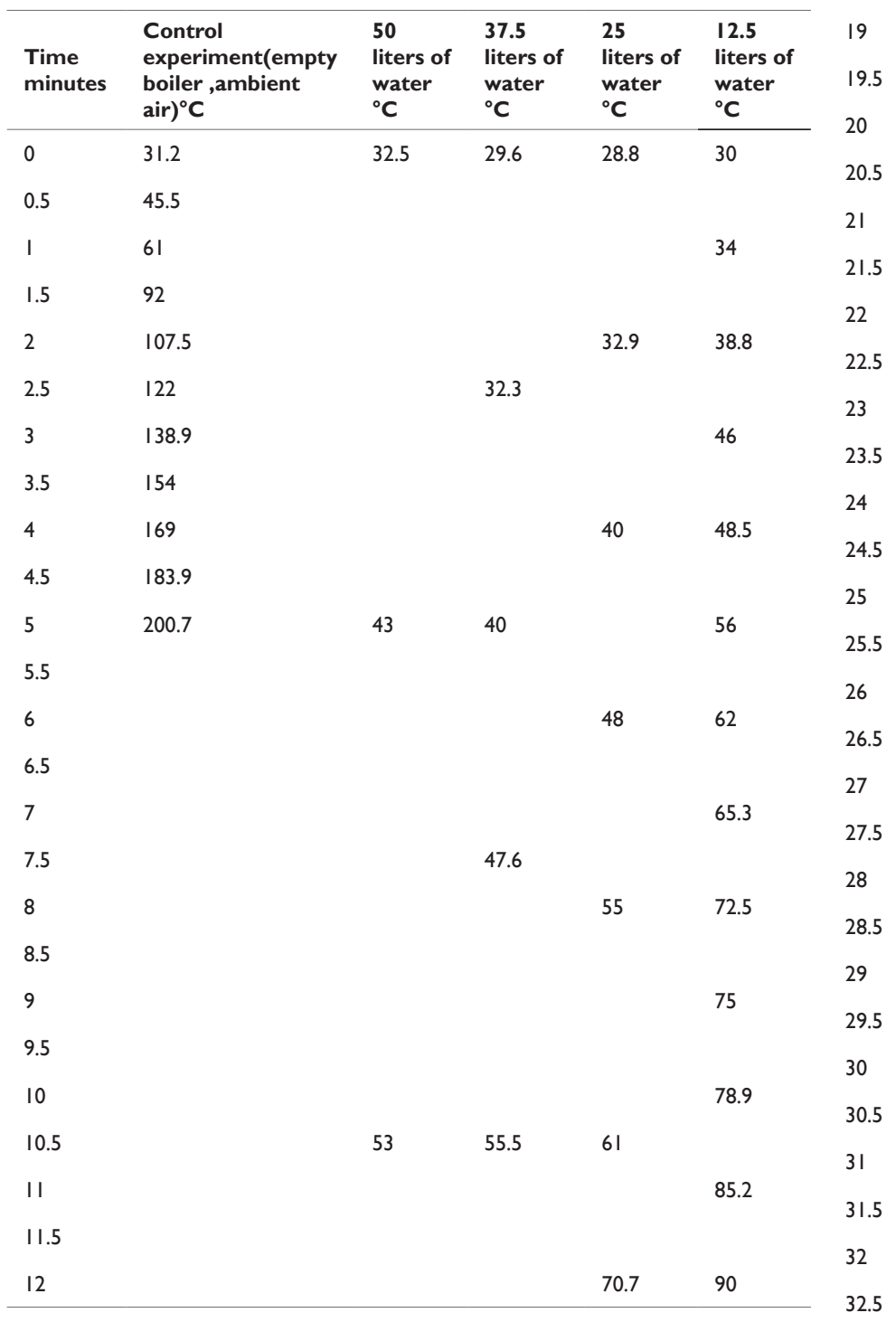

\section{Table Continues...}

\begin{tabular}{llllll} 
Time & Control & 50 & 37.5 & 25 & 12.5 \\
minutes & $\begin{array}{l}\text { experiment(empty } \\
\text { boiler, ambient } \\
\text { air) }{ }^{\circ} \mathrm{C}\end{array}$ & $\begin{array}{l}\text { liters of } \\
\text { water } \\
{ }^{\circ} \mathrm{C}\end{array}$ & $\begin{array}{l}\text { liters of } \\
\text { water } \\
{ }^{\circ} \mathrm{C}\end{array}$ & $\begin{array}{l}\text { liters of } \\
\text { water } \\
{ }^{\circ} \mathrm{C}\end{array}$ & $\begin{array}{l}\text { liters of } \\
\text { water } \\
{ }^{\circ} \mathrm{C}\end{array}$ \\
\hline
\end{tabular}

63

13

13.5 
Table 3Performance evaluation of boiling $33.75 \mathrm{~kg}$ of locust bean

\begin{tabular}{ll}
\hline Time minutes & ${ }^{\circ} \mathbf{C}$ \\
\hline 0 & 30 \\
5 & 35.2 \\
10 & 40.3 \\
15 & 44.9 \\
20 & 50.1 \\
25 & 55 \\
30 & 60.2 \\
35 & 64.8 \\
40 & 69.9 \\
45 & 75.1 \\
50 & 80.2 \\
55 & 85.2 \\
60 & 90 \\
\hline
\end{tabular}

\section{Discussion of results}

\section{Performance evaluation on the boiler}

Table 2 shows results of performance evaluation on the boiler. The machine was firstly evaluated while empty (ambient air), this was in accordance with the works of. ${ }^{24}$ At time zero the temperature was $31.2^{\circ} \mathrm{C}$ i.e. temperature of the surrounding. After power was supplied the temperature continuously increased and the time was taken at every 0.5 minutes. The machine attains the temperature of $200.7^{\circ} \mathrm{C}$ in 5 minutes. This was the maximum temperature attained and the temperature remains the same from 5 to 32.5 minutes. The temperature increase was not steady; this could be as a result of unsteady power supply. The boiler was secondly evaluated using 50 liters of water. The initial time and temperature were taken to be zero minutes and $31.20^{\circ} \mathrm{C}$ respectively. The temperature increased with time after power was supplied. At 15 minutes the water attained the temperature of $65.0^{\circ} \mathrm{C}$. This temperature remains the same up till 32.5 minutes which is the maximum time taken. This could be the maximum temperature the water can attain at 32.5 minutes, as a result of volume of water involved. The increase in time with continuous heating can rise the temperature above $65^{\circ} \mathrm{C}$. The next test was done using 37.5 liters of water. The initial time and temperature were zero minutes and $26.6^{\circ} \mathrm{C}$ respectively. The difference in the initial temperatures could be from changes in climatic conditions and time of the experiment. The temperature increases to $74.50^{\circ} \mathrm{C}$ in 20 minutes; it after wards rises up to $98.50^{\circ} \mathrm{C}$ in 32.5 minutes. Comparing increase in temperature difference of 50 liters of water and 37.5 liters of water, it could be observed that, the lager the volume of water, the slower the rate of temperature raise, and the smaller the volume of water the faster the rate of temperature raise. This is because more time and energy is required to raise the temperature of larger volume of water than the smaller volume. In the use of 25 liters of water, the initial time and temperature were zero minutes and $28.8^{\circ} \mathrm{C}$. The temperature rises up to $85^{\circ} \mathrm{C}$ in 20 minutes and after wards increases to $100^{\circ} \mathrm{C}$ in 25 minutes. This is the boiling point of water. The temperature remains the same up to 32.5 minutes, the maximum time taken. This can be seen from Figure 3. Comparing the volumes of water used for evaluation with regards to the time and temperature. In terms of their temperature increase it could be seen that the larger the volume of water the more the time in relation to temperature increase and vice versa (Figure 3).
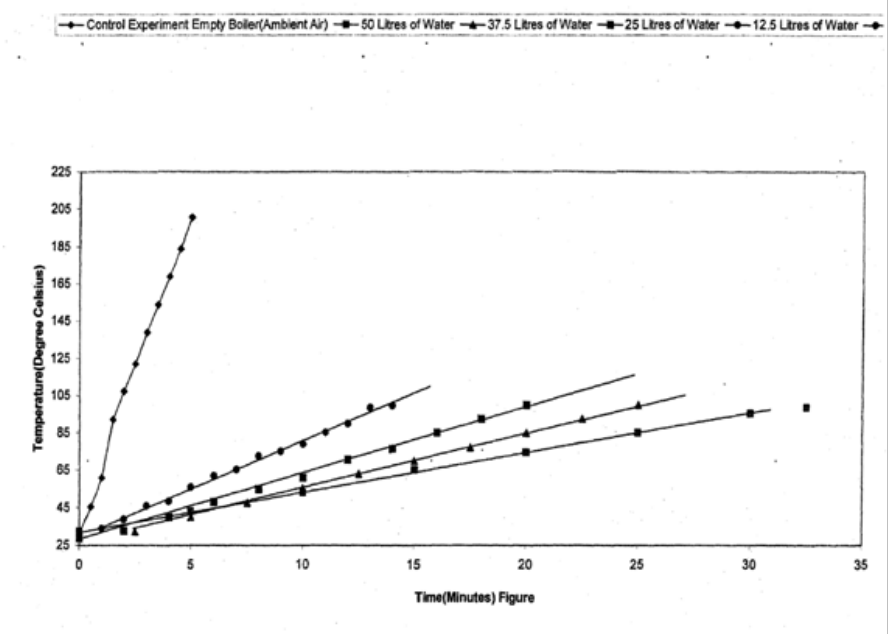

Figure 3 Graph of temperature variation with time in evaluating different volumes of water.

Lastly the boiler was evaluated using 12.5 liters of water. The initial time and temperature recorded were zero minute and $30^{\circ} \mathrm{C}$ respectively. The temperature increased unsteadily from $30^{\circ} \mathrm{C}$ to $99.6^{\circ} \mathrm{C}$ at the time interval of 1 minute up to 14 minutes and at 19.5 minutes the temperature attains $100.0^{\circ} \mathrm{C}$, (Figure 3). Comparing the different volumes of water used, it could be observed that volume is directly proportional to energy and time required to boil water. It could also be observed between 12.5 and 25 liters of water that temperature of $100^{\circ} \mathrm{C}$ was attained at 20 minutes for 12.5 liters of water and 25 minutes for 25 liters of water respectively. Generally the larger the volume of water the more time taken to rise its temperature when conditions remain the same.

\section{Performance evaluation of boiling locust bean}

Table 3shows the performance evaluation of the boiler using $33.75 \mathrm{~kg}$ of locust bean with 12.5 liters of water. This is in accordance with the procedure of Audu et al., ${ }^{25}$ in their research of developing a concentric cylinder locust bean dehuller. The initial time and temperature were zero minute and $30^{\circ} \mathrm{C}$ respectively. The temperature increases from $30^{\circ} \mathrm{C}$ to $90^{\circ} \mathrm{C}$, the temperature at which the locust bean was boiled, this is in agreement with the works of Oseni et. al., ${ }^{26}$ in their development of a locust bean processing device. The time interval with respect to temperature rise was 5 minues.

The maximum time taken during the boiling process was approximately 60 minutes. At this time and temperature of $90^{\circ} \mathrm{C}$ the locust bean was boiled. Comparing the rate of boiling between traditional (use of fire wood) and mechanized (electrically powered); it could be observed that the boiling time was drastically reduced from 12 hours to 1 hour. The temperature increase from $30^{\circ} \mathrm{C}$ to $90^{\circ} \mathrm{C}$ was not steady. This observation is in line with the result of Oseni et al., ${ }^{26}$ in their evaluation of locust bean device.

\section{Temperature on the outer surface of boiler}

Table 4 show temperatures outside the boiler at various times taken to conclude different performance evaluation test on the boiler. The temperature outside the boiler when empty was the highest, which was unanticipated. This could be as a result of the inability of the insulator used to withstand and contain the high temperature rise of $200.7^{\circ} \mathrm{C}$. It could also be observed that temperatures outside 
the boiler reduce downward (from highest volume to the lowest) with reduction in volume of water, this is as a result of the shorter time taken to complete an event. It could be seen that the smaller the volume, the shorter the time of completing event and the lower the temperature outside the boiler. Relating these observations to time taken to conclude the experiments, it could be observed that increase or decrease in time influence the temperature outside the boiler. This agrees with the findings of Aderoju ${ }^{20}$ in their works of developing a locust bean processing plant. The temperature outside the boiler at 60 minutes (time of concluding the boiling of $33.7 \mathrm{~kg}$ of locust bean) is $26.15^{\circ} \mathrm{C}$ which was the lowest temperature recorded.

Table 4Temperature on the Outer Surface of Boiler

\begin{tabular}{lll}
\hline $\begin{array}{l}\text { Time taken } \\
\text { to conclude } \\
\text { experiment } \\
\text { (minutes) }\end{array}$ & Event & $\begin{array}{l}\text { Temperature } \\
\text { outside the } \\
\text { boiler at the } \\
\text { end of the } \\
\text { experiment }\end{array}$ \\
\hline 5 & Empty & 68.5 \\
25 & 50 liters of water & 65.2 \\
20 & 37.5 liters of water & 60 \\
15.5 & 25 liters of water & 50.4 \\
13 & 12.5 liters of water & 40.5 \\
60 & $33.75 \mathrm{~kg}$ of locust bean & 26.15 \\
\hline
\end{tabular}

\section{Graph relating temperature with time in boiling $33.75 \mathrm{~kg}$ of locust bean}

The graph shows linear relationship between temperature and time. As the time increases temperature also increases i.e. temperature is proportional to time.

\section{Conclusions}

(1) A boiler machine was successfully designed, constructed, and evaluated

(2) A better and mechanized locust bean boiler was developed which boiled $33.75 \mathrm{~kg}$ of locust bean in 1 hour compared to 12 hours traditional method and therefore the sole objective of reducing time of boiling and saving the environment is achieved.

(3) The materials used are readily available and cost of construction is $\$ 20,207.5$ which is relatively moderate.

\section{Recommendations}

Owing to technological advancement worldwide, improvement should be made in the following areas; the preparation of feed water for boiler injection should be optimized by the removal of undesirable salts and contaminants. Modification should include; Adjustable thermostat $59-160^{\circ} \mathrm{F}$, Grounded heating element, spigot cut out, internal control thermocouple and a beeping device.

Various sizes of the boiler could be produced and made available in the market so that people can acquire then according to need.

\section{Acknowledgments}

The authors sincerely appreciate and acknowledge the effort of Osisienato Alabi as far as performance evaluation in this study is concerned.

\section{Conflicts of interest}

The author declares there are no conflicts of interest.

\section{Funding}

None.

\section{References}

1. Gernah DL, Iyang CU, Ezeora NL. Effect of Incubation Materials on Fermentation of Locust Bean (Parkia Boglobosa) in the Production of Dawadawa. International Journal of Food and Agricultural Research. 2004;1(2).

2. Campbell PG. African Locust Bean (Parkia Species) and it West African Fermented Food Product Dawadawa. Ecology of Food Nutrition. $1980 ; 132$

3. Ajayi OA. Design of a Thresher for Locust Bean. Agricultural Mechanization in Asia; Africa and Latin America. 1991;22(3).

4. Eleazu CO, Eleazu KC, Awa E, et al. Comparative study of the phytochemical composition of the leaves of five Nigerian medicinal plants. E3 J Biotech Pharm Res. 2012;3(2):42-46.

5. Chikezie PC, Agomuo EN, Amadi BA. Nutritive Values and Antioxidant Activity of Citrullus lanatus Fruit Extract. Mega soft publishers. 2008;2:51-53.

6. Eleazu CO, Okafor PN, Ahamefuna I. Total Antioxidant Capacity, Nutritional Composition and In hibitory Activity of Unripe Plantain (Musa paradisiacae) on Oxidative Stress in Alloxan Induced Diabetic Rabbits. Pakistan J Nutri. 2010;9(11):1052-1057.

7. Sobukola OP, Onwuka VI. Effect of Moiture Content on Some physical Properties of Locust Bean Seed (Parkia fillicoidea L.). Journal of Food Process Engineering. 2009;32-35.

8. Olajide JO, Ade-Omowaye BIO. Determination of Some Physical Properties of African Locust bean. Journal of Agicultural Engineering Research. 1999;(74)2:213-215.

9. Allan C. The Science of Food and Cooking. 1980. 188 p.

10. Mohammed GY, Adeshina F, Salman A. Design, Fabrication and Testing of a Manually Operated Locust Bean Cubing Machine. Asian Journal of Applied Sciences. 2018;11:56-63.

11. Oyewole OB, Odunfa SA. Effect of cooking method on water absorption and ease of dehulling in preparation of African locust beans for Iru: International Journal of Food science and Technology. 1990;(25)4:461-463.

12. Oloko SA, Agbetoye AS. Development and Performance Evaluation of a Melon Depodding Machine. Agricultural Engineering International: The CIGR Journal of Scientific Research and Development. Manuscript PM 06 018 Vol. VIII. August, 2006. 10 p.

13. Alabi DA. Akinsulire OR, Sanyanolu MA. Qualitative Determination of Chemical and Nutritional Composition of Parkia biglobosa (jacq.). Afr J Biotechnol. 2005;4(8):812-815.

14. Beaumomt M. Flavoring Composition Prepared by Fermentation with Bacillus spp. Int J Food Microbiol. 2002;75:189-196.

15. Omafuvbe BO, Falade OS, Osuntogun BA, et al. Chemical and Biochemical Changes in African Locust Bean (Parkia bilobosa) and Melon (Citrullus vulgaris) Seeds During Fermentation to Condiments. Pakistan Journal of Nutrition. 2004;3(3):140-145.

16. Abigail A. Technological Transitions: Technical Upgrading of indigenous Food Technologies in Africa. Food Security and Sustainable Development Division (FSSDD), Economic Commission for Africa, Addis Ababa, Ethiopia; 2000. 34 p. 
17. Ryder G.H. Strength of Materials 3rd edn. In S.I Units. Macmillan; 1968. p. $65-85$.

18. Taylor RA. Socioeconomic impacts of heat transfer research. International Communications in Heat and Mass Transfer. 2012;39(10):1467-1473.

19. Earle RL. Unit Operations in Food Processing. Published by NFIFST (Inc.); 1983.

20. Aderoju AA. Development of a Locust Bean Processing Plant. A Graduate Thesis, Federal University of Technology, Minna, Unpublished.

21. Gbabo A, Liberty JT, Fadele OS. Design, Construction and Assessment of African Locust Bean (Parkia biglobosa) Dehuller and Seperator. International Journal of Engineering and Innovative Technology (IJEIT). 2013;3(5).
22. Sahay KM, Singh KK. Unit Operation of Agricultural Processing; Introduction to Steam Boilers and Steam Rising. 1970. p. 56-57.

23. Cole KD, Beck JV, Haji-Sheikh A, et al. Heat Conduction Using Green's Functions. 2nd edn. CRC Press; 2011.

24. Khurmi RS, Gapta JA. A textbook on Machine Design. New Delhi, Eurasia Publishing House; 2004. 56 p.

25. Audu AO, Umar B. Development of A Concentric Cylinder Locust Bean Dehuller. Agricultural Engineering International: The CIGR Journal of Scientific Research and Development. Manuscript PM 04 003. Vol. VI. 2004.

26. Oseni O, Dare AA, Gbenga AO, et al. Development of a locust bean processing device. Journal of Food Science and Technology-Mysore. 2013;50(2):248-256. 